\title{
Feeding different levels of vitamin $E$ and selenium has no effect on serum immunoglobulin Y (IgY) production by layers vaccinated against Escherichia coli and avian encephalomyelitis virus
}

\author{
Alimentação com diferentes níveis de vitamina $E$ e selênio não influencia a produção de imunoglobulina \\ Y (IgY) no soro de poedeiras leves vacinadas contra Escherichia coli e encefalomielite aviária
}

\author{
Giselle Kindlein $^{\mathrm{I}}$ Andréa Machado Leal Ribeiro ${ }^{\mathrm{II}}$ Cláudio Wageck Canal ${ }^{\mathrm{III}}$ \\ Maitê de Moraes VieiraI
}

\begin{abstract}
The effects of vitamin $E$ and selenium (Se) supplementation on the immunity of hens vaccinated against a mixture of six swine-pathogenic Escherichia coli (EC) and avian encephalomyelitis virus (AEV) were studied. Antibody production $(A b P)$ was evaluated in ninety 49 to 57 -weekold H\&N Nick Chick hens fed diets containing 14IU Vitamin E $\mathrm{kg}^{-1}$ (basal diet), 27, 59, 111, or 111IU vitamin $\mathrm{K} \mathrm{kg}^{-1}+$ $0.56 p p m$ Se supplementation. At 51 wks of age, half of the hens were vaccinated against $E C$, and all birds were vaccinated against AEV. At 53-weeks of age, the birds received a second dose of $E C$ vaccine. Blood samples were collected weekly and serum was analyzed by ELISA for antiEC IgY and was expressed as optical density (OD). Vaccinated hens had higher serum $O D$ than the non-vaccinated hens $(P \leq 0.05)$. Vaccinated hens fed 27 and $59 I U$ of vitamin $E / \mathrm{kg}$ had a higher $(P<0.05)$ serum OD than hens fed 111IU + Se. Neither EC nor AEV seem to be appropriate models for the study of the influence of micronutrients on immune responsiveness of older hens.
\end{abstract}

Key words: avian encephalomyelitis, Escherichia coli, immunoglobulin, selenium, vitamin E.

\section{RESUMO}

Os efeitos da suplementação de vitamina $E$ e Selênio (Se) na imunidade de galinhas vacinadas contra uma mistura de 6 sorotipos patogênicos de Escherichia coli (EC) $e$ $o$ vírus da encefalomielite aviária (VEA) foram estudados. A produção de anticorpos foi avaliada em galinhas $H \& N$ Nick Chick durante a 49a e 57 semanas de vida. As aves foram alimentadas com dietas contendo 14 UI de Vitamina $\mathrm{E} \mathrm{kg}^{-1}$ (dieta basal), 27, 59, 111 e 111UI de Vitamina $E \mathrm{~kg}^{-1}+0,56 \mathrm{ppm}$
Se suplementar. Às 51 semanas de idade, metade das galinhas foi vacinada contra EC, e todas as aves foram vacinadas contra VEA. Às 53 semanas, as aves receberam a segunda vacina contra EC. Amostras de sangue foram coletadas semanalmente e o soro foi analisado por ELISA para anti-EC IgY e expresso como densidade óptica (DO). Galinhas vacinadas tiveram maior DO do que as não-vacinadas $(P<0,05)$. Aves vacinadas que receberam 27 e 59 UI de vitamina E/kg tiveram maior DO do soro $(P<0,05)$ do que as alimentadas com $111 \mathrm{UI}+\mathrm{Se}$. Os antígenos utilizados mostraram não ser modelos satisfatórios para estudar a influência de micronutrientes na resposta imune de aves mais velhas.

Palavras-chave: encefalomielite aviária, Escherichia coli, imunoglobulina, selênio, vitamina $E$.

\section{INTRODUCTION}

Diet characteristics can modulate the sensitivity of birds to infectious challenges, and the type and level of each ingredient can affect bird immunity (KLASING, 1998). This suggests that it is possible to increase the amount of specific IgY, which corresponds to IgG in mammals, in the serum of poultry challenged with an antigen, and therefore, in their eggs, by means of the diet.

Vitamin E influences cells of the immune system, such as lymphocytes and macrophages (GEBREMICHAEL et al., 1984). It also has beneficial

\footnotetext{
${ }^{\mathrm{I}}$ Curso de Pós-graduação em Zootecnia, Universidade Federal do Rio Grande do Sul (UFRGS), Porto Alegre, RS, Brasil.

"Departamento de Zootecnia, UFRGS, Av. Bento Gonçalves 7712, 91540-000, Porto Alegre, RS, Brasil. E-mail: aribeiro@ufrgs.br. Autor para correspondência.
}

"IIDepartamento de Medicina Animal, UFRGS, Box 15094, Porto Alegre, RS, Brasil. 
effects on immunocompetence, limiting the production of prostaglandins and leukotriens, which are powerful inducers of inflammation, and alters the release of cytokines (CHUNG \& BOREN, 1999). KIDD (2004) mentions increments in thymus and spleen cell $\mathrm{T}$ population for broilers supplemented with this vitamin. Also, KONJUFCA et al. (2004) observed, in 3-wk broilers, that 110 to $220 \mathrm{UI} \mathrm{kg}^{-1}$ of vitamin $\mathrm{E}$ influenced positively the macrophage phagocytic function. ZHU et al. (2003) using 200UI kg-1 of vitamin E, found a significant increment of $\mathrm{T}$ lymphocytes in turkeys challenged with Lysteria monocytogenes. PUTHPONGSIRIPORN et al. (2001) observed a higher lymphocyte proliferation in vitro with layers feed 65UI $\mathrm{kg}^{-1}$ of vitamin $\mathrm{E}$ and $1000 \mathrm{ppm} \mathrm{kg}^{-1}$ of vitamin $\mathrm{C}$ together. LESHCHISKY \& KLASING (2001) showed that

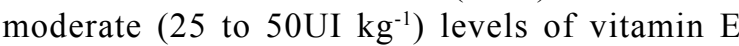
supplementation were more appropriate and that high levels were less effective for broilers challenged with infectious bronchitis virus and sheep red blood cells.

Selenium (Se) is a part of the natural antioxidant system, sparing vitamin E (COMBS et al., 1975) and increasing glutathione peroxidase activity (SURAI, 1998). Experiments on the immunological effects of Se supplementation suggested that IgM and IgG antibody responses could be boosted most effectively by concentrations considerably in excess of those required for normal growth, but other work has shown that such results depend on species, age, sex and antigen (TURNER \& FINCH, 1991). HEGAZY $\&$ ADACHI (2000) found better immune response against Salmonella typhimurium infection when 1 ppm of Se was supplemented on the diet. Sources of Se should be considered also. Organic Se was more efficient than inorganic form in the synthesis of bovine IgM (in vitro) (FINCH \& TURNER, 1996).

Vaccination initiates a primary humoral and/ or cell mediated immune reaction. Antibodies can usually be detected some days after the vaccination and can increase up to the $14^{\text {th }}$ day and then start to decline. The response to a second immunization (secondary immune response) is faster and reaches higher levels of antibodies (TIZARD, 2002). Therefore, the possibility to increase IgY production by nutrition in combination with a vaccination schedule warrants further investigation.

This study focused on the possible relationship between dietary vitamin $\mathrm{E}$ and Se and specific IgY titers in the serum of layers vaccinated against EC related to swine colibacillosis. Also, the relationship between those nutrients and the production of antibodies against AEV was evaluated. This virus was chosen believing the absence of specific antibodies in the birds. The main pathogen was chosen in order to produce eggs enriched with antibodies against swine $\boldsymbol{E}$. coli to feed piglets to prevent neonatal diarrhea (RUDNIK et al., 2005).

\section{MATERIAL AND METHODS}

The experiment was conducted with 90 H\&N Nick Chick layers acquired with 48 weeks of age from a commercial flock without receiving previous vaccinations against E.coli related to swine colibacillosis or avian encephalomyelitis virus. Birds were individually housed in cages in an environment with controlled temperature $\left( \pm 22^{\circ} \mathrm{C}\right)$, with 16 hours of light day ${ }^{-1}$. At the beginning of the experiment, the hens were weighed, selected, and distributed among treatment groups by similar body weights $(\mathrm{P}=0.79)$.

During the stage of adaptation, from 48 to 49 weeks of age, birds were fed a unique preexperimental diet. On day 0 of the experimental period (at 49 weeks of age), birds were fed a mash diet, containing different vitamin E concentrations and Se. The basal diet, independently of the supplementation, contained 10IU of vitamin E, $0.18 \mathrm{mg}$ of selenium and $2800 \mathrm{kcal}$ ME per $\mathrm{kg}$ of feed, $17 \%$ crude protein, $0.8 \%$ lysine and $0.72 \%$ methionine + cystine.

Birds were distributed into 10 treatment groups. The treatments were: $\mathrm{T} 1-$ feed without vitamin E supplementation; T2 - supplementation of 50IU vitamin $\mathrm{E} \mathrm{kg}^{-1}$ feed; T3 - supplementation of 150IU vitamin $\mathrm{E} \mathrm{kg}^{-1}$ feed; T4 - supplementation of 250IU vitamin $\mathrm{E} \mathrm{kg}^{-1}$ feed; and T5 - supplementation of $250 \mathrm{IU}$ vitamin $\mathrm{E} \mathrm{kg}^{-1}$ feed and additional 0.3ppm Se as sodium selenite. Treatments 6 to 10 were the same as treatments 1 to 5 , but birds in treatments 6 to 10 were vaccinated for E. coli. Vitamin E and Se were analyzed in diet and, due to the differences comparing calculated values, responses are discussed based on analyzed values. Vitamin E was analyzed by Roche ${ }^{\circledR}$, Jalisco, México, and Se was analyzed by Laborquímica, Porto Alegre, Brasil. The levels of vit $\mathrm{E}$ and Se were chosen due to other experiments (LESHCHINSKY \& KLASING, 2001) and practical levels used in industry.

At 51 weeks of age (two weeks after the experimental diets were fed initially), blood was collected from each bird in order to control the level of specific antibodies against $\boldsymbol{E}$. coli and avian encephalomyelitis virus (AEV) (Collection 1- Control). Immediately after the first collection of blood, birds in treatments 6 to 10 were vaccinated for $\boldsymbol{E}$. coli, using $0.5 \mathrm{~mL}$ of a commercial vaccine Enterovac-S, Laboratório IRFA, containing formalin inactivated $10^{9}$ bacterial cells $\mathrm{mL}^{-1}$, resuspend in water emulsion, produced from $6 \boldsymbol{E}$. 
coli serotypes related to swine colibacillosis (K12:K88ab, O157:K88ac, O8:K87:K88ad, 987P, O101:K30:F41, K99). Birds from treatments 1 to 5 received phosphate buffered saline (PBS) in the same dose. The vaccine and PBS were administered in the breast muscle, and the adjuvant used was aluminum hydroxide. The second vaccination, using the bacterin or PBS as a booster, was performed 2 weeks later, when birds were 53 weeks of age.

The live avian encephalomyelitis virus vaccine (Porvac-AE; Fort Dodge Lab) was applied to all birds, also at 51 weeks of age, via dilution of the vaccine in the water of a common drinker. At 1 and 2 weeks after the primary E.coli vaccination and at 1, 2, and 3 weeks after the secondary booster vaccination, blood samples were collected from the wing veins of all birds (Collections 2, 3, 4, 5 and 6 respectively). Blood samples were incubated at $37^{\circ} \mathrm{C}$ for one hour and centrifuged at $10,000 \mathrm{x}$ g for 3 minutes in order to obtain a clarified serum. All serum samples were stored at $20^{\circ} \mathrm{C}$.

The quantification of IgY against $\boldsymbol{E}$. coli in the sera was performed by indirect ELISA (Enzyme Linked Immuno Sorbent Assay). Briefly, the same bacterin without adjuvant was diluted $1: 10,000$ in 0.1 $\mathrm{M} \mathrm{Na}_{2} \mathrm{Co}_{3}-\mathrm{NaHCO}_{3}$ buffer, $\mathrm{pH} 9.6$ and used for coating of microtitration plates (100 $\mu \mathrm{L} /$ well) (Maxisorp, A/S Nunc, Kamstrub, Denmark). After an incubation period of 14 hours at $4^{\circ} \mathrm{C}$ in a humid chamber, plates were washed three times with washing buffer $(0.1 \mathrm{M} \mathrm{NaCl}$; 0.002 M Tris; $0.05 \%$ Tween $20 ; \mathrm{pH} 7.4 ; 1 \%$ skimmed milk powder). Serum was diluted in washing buffer and incubated at room temperature in a humid chamber for 60 minutes. Plates were washed as described above and bound antibody was detected using goat antichicken IgY peroxidase labeled conjugate (Kirkegaard and Perry Laboratories (KPL), Gaithersburg, Maryland USA) diluted 1:1,000 in washing buffer. Plates were incubated at room temperature in a humid chamber for an additional 60 minutes and washed three times in washing buffer without skimmed milk powder. The chromogen solution ( $3.4 \mathrm{mg} \mathrm{OPD}, 5 \mu \mathrm{L} \mathrm{H}_{2} \mathrm{O}_{2} 30$ vol. in $10 \mathrm{~mL}$ of citrate-phosphate buffer) was added and plates were incubated for 20 minutes at room temperature in the dark. The reaction was blocked with $50 \mu \mathrm{L}_{\text {of }} \mathrm{H}_{2} \mathrm{SO}_{4}$ $12.5 \%$. Optical density (OD) was measured by an ELISA reader (Titertek multiscan $\mathrm{MC}$ ) at a wavelength of 490nm.

The quantification of antibodies against AEV was made by ELISA, with a commercial kit (KPL), and using only sera of Collection 1 (control) and 4 . The timing was justified by the fact that it is a common practice in the field to serologically monitor AEV 4 weeks after vaccination (MARTINS, 2000). The AEV titers in Collection 1 and 4 were also calculated by the Profile software from KPL.

Optical density of the sera (OD) was analyzed. Statistical analyses of ELISA observations for $\boldsymbol{E}$. coli of each serum sample were conducted in duplicate for OD determination, considered as the average of two replicated samples minus the blank (optical density of all reagents except serum). As for $\mathrm{AEV}$, single analyses of each sample were performed.

A completely randomized experimental design was used, with one bird considered the experimental unit and nine birds per treatment. Treatments were analyzed in a $5 \times 2$ factorial arrangement of treatments (supplementation and vaccination). The data were submitted to analyses of variance using the General Linear Models Procedure (SAS Institute, 1989). The OD results among treatments were compared by Least Square Means of the General Linear Models Procedure, considering the optical density value of the control serum (collected before the first vaccination) as the co-variable.

\section{RESULTS AND DISCUSSION}

The analyzed feed levels of vitamin $\mathrm{E}$ and Se were different from those calculated (Table 1). For Se, two samples were analyzed (supplemented or not) and that is why no variation appears among treatments $1,2,3,4,6,7,8$ and 9 . For vitamin $\mathrm{E}$, one sample for each diet was analyzed. The observed differences may have been due to mixing or sampling problems. Both analytical methods accept low CV levels (around 10\%). The responses will be discussed based on analyzed values.

The statistical analysis of ELISA optical densities (OD) for $\boldsymbol{E}$. coli did show significance for vaccine $(\mathrm{P}<0.0001)$, Collection $(\mathrm{P}<0.0001)$, but did not show significant interactions between supplementation and collection. However, there were significant interactions between vaccine and collection $(\mathrm{P} \leq 0.0001)$ and supplementation and vaccine $(\mathrm{P} \leq 0.03)$. Therefore, the main effects will not be discussed, but the significant interactions are considered.

The OD responses during the experimental period as a function of the vaccination effect and sera data collection for all treatments are presented in table 2. As expected, all sera had a similar OD in the first collection before vaccination had occurred. E. coli vaccinated birds presented increased antibody response as compared to the non vaccinated birds $(\mathrm{P} \leq 0.05)$. The OD was directly related to the specific quantity of $\operatorname{IgY}$ against $\boldsymbol{E}$. coli present in the serum in vaccinated birds.

Ciência Rural, v.37, n.5, set-out, 2007. 
Table 1 - Analyzed and calculated vitamin E and selenium levels in the experimental diets.

\begin{tabular}{lcc}
\hline \multirow{2}{*}{ Treatments } & Vitamin E (IU kg-1) & Selenium (ppm) \\
\cline { 2 - 3 } & Analyzed (calculated) & Analyzed (calculated) \\
\hline 1 and 6 & $14(10)$ & $0.16(0.18)$ \\
2 and 7 & $27(60)$ & $0.16(0.18)$ \\
3 and 8 & $59(160)$ & $0.16(0.18)$ \\
4 and 9 & $111(260)$ & $0.16(0.18)$ \\
5 and 10 & $111(260)$ & $0.72(0.48)$ \\
\hline
\end{tabular}

Vaccinated birds showed a significant increase in OD during the two weeks following the first vaccination (Collection 2 and 3), and the OD values were further elevated during the two weeks after the second vaccination (Collection 4 and 5). In collection 6 there was a decreased OD for vaccinated birds, but these OD values were not significantly different from those found during the two weeks following the first vaccination. These responses to serial vaccinations represent typical primary and secondary humoral immune responses to an antigen challenge.

Non-vaccinated birds did not show significant time-dependent differences when the control was compared with Collection 2, 3, and 6, but, in collection 4 and 5, OD values were significantly higher than control values. This was not expected without an additional challenge. FRIEDMAN et al. (1998) made a similar observation, and TENGERDY \& NOCKELS (1975) also reported the non-vaccinated negative control group to have developed a very high antibody titer against $\boldsymbol{E}$. coli. In the former study, time-dependent increase in antibody titers was believed to be due to contact with bacteria in their environment.

Table 2 also presents OD during the experimental period as a function of supplementation effect. For this analysis, Collection 1 was neglected since birds from vaccinated group were not vaccinated yet. Within the non-vaccinated group, birds fed 27IU had lower OD as compared to those receiving the basal diet and the one containing 59IU of vitamin E. This unexpected result may be due to the difficulty of correctly quantifying the specific immunoglobulins produced against $\boldsymbol{E}$. coli, an organism that is widely distributed in the environment. This means that, due to previous contact with this microorganism, birds can have different immunoglobulin levels, which cannot be explained merely by the effect of vaccination or of supplementation. These differences were not statistically different when the sera of the first Collection (Collection 1) were compared $(\mathrm{P} \leq 0.47)$. However, the coefficient of variation found in the initial optical density analysis of the bird's sera was very high (64.45\%).

Among the vaccinated birds, there were also differences in OD as a function of supplementation. The level of $111 \mathrm{IU}$ vitamin $\mathrm{E}+$ Se produced lower antibody levels than those seem when 27 and 59IU

Table 2 - Optical density (OD) obtained by ELISA in the sera of birds vaccinated and non-vaccinated against $\boldsymbol{E}$. coli as a function of collection date, vitamine $\mathrm{E}$ and selenium level in diet.

\begin{tabular}{|c|c|c|c|}
\hline & Weeks & Non-vaccinated & Vaccinated \\
\hline \multicolumn{4}{|c|}{ Collection } \\
\hline 1 & 51 -Control & $0.73 \pm 0.044 \mathrm{bA}$ & $0.76 \pm 0.043 \mathrm{dA}$ \\
\hline \multicolumn{4}{|c|}{$1^{\text {st }}$ vaccination } \\
\hline 2 & 52 & $0.85 \pm 0.043 \mathrm{abB}$ & $1.02 \pm 0.042 \mathrm{cA}$ \\
\hline 3 & 53 & $0.82 \pm 0.043 \mathrm{abB}$ & $1.08 \pm 0.042 \mathrm{bcA}$ \\
\hline \multicolumn{4}{|c|}{$2^{\text {nd }}$ vaccination } \\
\hline 4 & 54 & $0.90 \pm 0.041 \mathrm{aB}$ & $1.31 \pm 0.041 \mathrm{aA}$ \\
\hline 5 & 55 & $0.88 \pm 0.041 \mathrm{aB}$ & $1.30 \pm 0.041 \mathrm{aA}$ \\
\hline 6 & 56 & $0.83 \pm 0.043 \mathrm{abB}$ & $1.16 \pm 0.043 \mathrm{bA}$ \\
\hline \multicolumn{4}{|c|}{ Vitamin $\mathrm{E}+\mathrm{Se}\left(\mathrm{IU}\right.$ vitamin $\left.\mathrm{E} \mathrm{kg}^{-1}\right)$} \\
\hline 14 & & $0.92 \pm 0.039 \mathrm{a}$ & $1.09 \pm 0.038 \mathrm{ab}$ \\
\hline 27 & & $0.75 \pm 0.039 \mathrm{~b}$ & $1.15 \pm 0.039 \mathrm{a}$ \\
\hline 59 & & $0.87 \pm 0.039 \mathrm{a}$ & $1.16 \pm 0.039 \mathrm{a}$ \\
\hline 111 & & $0.81 \pm 0.039 \mathrm{ab}$ & $1.10 \pm 0.038 \mathrm{ab}$ \\
\hline $111+\mathrm{Se}$ & & $0.83 \pm 0.038 \mathrm{ab}$ & $1.03 \pm 0.039 \mathrm{~b}$ \\
\hline
\end{tabular}

Means within a column with no common small letters are different $(\mathrm{P} \leq 0.05)$

Means within a row with no common capital letters are different $(\mathrm{P} \leq 0.05)$.

Ciência Rural, v.37, n.5, set-out, 2007. 
vitamin $\mathrm{E} \mathrm{kg}^{-1}$ was fed, but there were no differences between the OD values for 0 and $111 \mathrm{IU}$ of vitamin $\mathrm{E}$ supplementation.

SELL et al. (1997) and FRIEDMAN et al. (1998) showed controversial results as to the value of excessive vitamin $\mathrm{E}$ for birds, suggesting that there is an interaction between genotype and immune response. LESHCHINSKY \& KLASING (2001) suggested that high vitamin $\mathrm{E}$ levels in the feed might change the number and the function of the T-helper lymphocytes and modulate the production of cytokines, the activation of B-cells, and therefore, the level of specific antibody. These researchers observed that vitamin $\mathrm{E}$ supplementation between 25 and $50 \mathrm{IU} \mathrm{kg}^{-1}$ presented the highest immunomodulator effect. Higher levels were less effective. In the same study, vitamin E levels higher than 50IU $\mathrm{kg}^{-1}$ feed had a negative effect on the production of antibody against sheep red blood cells. Some researchers showed that the effects of vitamin $\mathrm{E}$ on humoral immune response (antibody production) are influenced by age. Most of the reviewed studies, in which vitamin $E$ had an immunomodulator effect, were conducted with young birds. Due to age, hens used in this experiment could have adequate storage of vitamin $\mathrm{E}$.

Selenium supplementation had no effect on the OD of the sera of either non-vaccinated or of vaccinated birds, as observed by the comparison of the treatments supplemented with 111IU of vitamin E with those supplemented with $111 \mathrm{IU}$ vitamin $\mathrm{E}+\mathrm{Se}$ (Table 2).

In the avian encephalomyelitis virus analysis, table 3 shows that antibody production was influenced by supplementation accepting a probability of $0.13(\mathrm{P} \leq 0.13)$. Birds receiving $111 \mathrm{IU}$ of vitamin $\mathrm{E}$ in the diet produced less antibody than those fed 59IU and the control group. Birds fed 111IU of vitamin E plus Se produced more antibody than those receiving

Table 3 - Effect of vitamin E and selenium level in diet onlthe optical density (OD) obtained by ELISA of the sera of birds vaccinated against avian encephalomyelitis in collection 4.

\begin{tabular}{ll}
\hline Vitamin E $\left(\mathrm{IU} \mathrm{kg}^{-1}\right)$ & $\mathrm{OD}$ \\
\hline 14 & $0.63 \pm 0.038 \mathrm{a}$ \\
27 & $0.60 \pm 0.034 \mathrm{ab}$ \\
59 & $0.63 \pm 0.034 \mathrm{a}$ \\
111 & $0.53 \pm 0.031 \mathrm{~b}$ \\
$111+\mathrm{Se}$ & $0.63 \pm 0.037 \mathrm{a}$ \\
\hline
\end{tabular}

Means within a column with no common letters are different $(\mathrm{P} \leq 0.05)$. only $111 \mathrm{IU}$ of vitamin E. The aim of using this virus to verify the effect of supplementation was to obtain initial sera with low levels of specific antibody. Although the birds in this experiment were not previously vaccinated against $\mathrm{AEV}$, they presented a fair amount of antibody in the serum even before the challenge.

\section{CONCLUSIONS}

Vaccination increased the amount of $\operatorname{IgY}$ against swine-pathogenic Escherichia coli in the serum of the birds and it is a technique that can be employed to produce hyper-immune eggs. Intermediate supplementation levels of vitamin E produced higher antibody quantities in the challenged birds as compared to those receiving the highest level. As a function of the positive response against avian encephalomyelitis virus, selenium seemed to be an important mineral to stimulate immune system, but the ideal level, as well as the bioavailability of the sources, must be further investigated.

Neither $\boldsymbol{E}$. coli nor the avian encephalomyelitis virus were appropriate pathogens for the development of this study due to the high OD in the initial sera of the birds. The use of antigens such as sheep red blood cells, which are completely unknown by the bird's immune system in nature, may be a methodological alternative.

\section{AKNOWLEDGMENTS}

To CNPq for the scholarship for Andréa Machado Leal Ribeiro and Claudio W. Canal

\section{REFERENCES}

CHUNG T.K.; BOREN B. Vitamin E use in commercial flocks examined. Feedstuffs, v.71, n.37, p.11, 1999.

COMBS G.F. et al. Mechanism of action of selenium and vitamin $\mathrm{E}$ in protection of biological membranes. Federation Proceedings, v.34, p.2090-2095, 1975.

FINCH J.M; TURNER R.J. Effects of selenium and vitamin E on the immune responses of domestic animals. Research of Veterinary Science, v.60, p.97-106, 1996.

FRIEDMAN, A. et al. Humoral immune response impairment following excess vitamin E nutrition in the chick and turkey. Poultry Science, v.77, n.7, p.956-962, 1998.

GEBREMICHAEL A. et al. Adherent cell requirement for the effect of vitamin $E$ on in vitro antibody synthesis. Journal of Nutrition, v.114, p.1297-1305, 1984.

HEGAZY S.M., ADACHI Y. Comparison of effects of dietary selenium, zinc, and selenium and zinc supplementation on growth and immune response between chick groups that were inoculated with Salmonella and aflatoxin or Salmonella. Poultry Science, v.79, p.331-335, 2000. 
KIDD M.T. Nutritional modulation of immune function in broilers. Poultry Science, v.83, p.650- 657, 2004.

KLASING K.C. Nutritional modulation of resistance to infectious diseases. Poultry Science, v.77, p.1119-1125, 1998.

KONJUFCA V.K. et al. Influence of dietary vitamin E on phagocytic functions of macrophages in broilers. Poultry Science, v.83, p.1530-1534, 2004.

LESHCHINSKY T.V.; KLASING K.C. Relationship between the level of dietary vitamin $\mathrm{E}$ and the immune response of broiler chickens. Poultry Science, v.80, p.1590-1599, 2001.

MARTINS P.C. Encefalomielite aviária. In: BERCHIERI, JR.; MACARI, M. Doenças das aves. Campinas: FACTA, 2000. p. 351-358.

PUTHPONGSIRIPORN, U. et al. Effects of vitamin E and C supplementation on performance: in vitro lymphocyte proliferation and antioxidant status of laying hens during heat stress. Poultry Science, v.80, p.1190-1200, 2001.

RUDNIK, L. et al. O uso de gemas de ovos de aves hiperimunizadas contra Esherichia coli suína no controle da diarréia neonatal de leitões. Revista Brasileira de Zootecnia, v.34, p.1234-1239, 2005.
SAS Institute INC. SAS/STAT User's Guide: version 6. 4.ed. Cary. NC, 1989. p.1-493.

SELL J.L. et al. Influence of supplementing corn-soybean meal diets with vitamin $\mathrm{E}$ on performance and selected physiological traits of male turkeys. Poultry Science, v.76, p.1405-1417, 1997.

SURAI P.F. Effect of selenium and vitamin E content of the maternal diet on the antioxidant system of the yolk and the developing chick. British Poultry Science, v.41, p.235243, 1998

TENGERDY R.P.; NOCKELS C.F. Vitamin E or vitamin A protects chickens against $\boldsymbol{E}$. coli infection. Poultry Science, v.54, p.1292-1296, 1975.

TIZARD I. Imunologia veterinária: uma introdução. 6.ed. São Paulo: Roca. 2002. 532p.

TURNER R.J.; FINCH J.M. Selenium and the immune response. Proceedings of the Nutrition Society, v.50, p.275-285, 1991.

ZHU, M et al. The role of dietary Vitamin $\mathrm{E}$ in experimental Listeria monocytogenes infections in turkeys. Poultry Science, v.82, p.1559-1564, 2003. 